\title{
Towards the development of environmental indices for the Namibian shelf, with particular reference to fisheries management
}

\author{
$\mathrm{CH}$ Bartholomae* and AK van der Plas \\ National Marine Information and Research Centre, PO Box 912, Swakopmund, Namibia \\ * Corresponding author, e-mail: cbartholomae@mfmr.gov.na
}

\begin{abstract}
The Namibian Ministry of Fisheries and Marine Resources has the task of collecting and providing relevant oceanographic information for management of their fisheries. However, quality information is difficult to provide because of the complexity of the processes involved in the Namibian marine ecosystem. Nonetheless, there are oceanographic data available that can contribute to fisheries management by improving the general understanding of important oceanographic processes related to fisheries. The focus of this paper is
\end{abstract}

on the development of simple environmental indices that can serve as a measurement or proxy of the state or intensity of certain important oceanographic processes or variables for temporal comparison. These indices relate to oceanographic processes such as upwelling, frontal movements, anoxic bottom conditions and biological indicators, which can be updated on a regular basis to provide a long-term perspective of the particular processes to management and marine scientists.

Keywords: chlorophyll a, dissolved oxygen, environmental index development, Namibia, remote sensing, SST, temperature

\section{Introduction}

The Benguela Current is one of the major upwelling ecosystems worldwide and exhibits large environmental variability on both spatial and temporal scales (Parrish et al. 1983, Shannon 1985, Shannon and Nelson 1996). The northern Benguela has experienced large fluctuations in fish stocks over many hundreds of years, as reflected in historical fishscale records (Baumgartner et al. 2004). Fish stocks such as sardine Sardinops sagax and hake Merluccius spp. have formed the basis of the Namibian pelagic and demersal fishing industry for the past five decades. Sardine stocks have decreased markedly from several million tons in the 1950 s and 1960s to a few hundred thousand tons in recent years (Boyer and Hampton 2001). Currently, the sardine industry relies heavily on the variable annual recruitment of sardine for its catches, making them susceptible to environmental impacts. An example of this occurred in 1996 when a zero total allowable catch (TAC) was set for sardine on account of their extremely low stock levels (CHB, unpublished data). The negative impacts of the 1995 Benguela Niño on the ecosystem probably contributed to that scenario, and underlines the influence of environmental variability on fish stocks. Fish mortalities of sardine and horse mackerel Trachurus trachurus capensis (among other species) were reported off northern Namibia and southern Angola at the peak of the Niño event in March 1995 (Gammelsrød et al. 1998). There is also strong evidence that during that event the warm water intrusion caused the sardine shoals to move southwards, which made them easily accessible to the fishing fleet (Gammelsrød et al. 1998, Boyer and Hampton 2001).
The hake fishery off Namibia started during the late 1950s. Catch rates increased sharply and an average of 500 000-600 000 tons were caught annually between 1973 and 1990 (Payne 1989, van der Westhuizen 2001). Since independence in 1990, catches have ranged between 55000 tons and 200000 tons. Major low-oxygen events, such as the one during the period 1993-1994 that occupied most of the central and northern Namibian shelf, have been linked to catastrophic losses of almost an entire cohort of juvenile hake (Woodhead et al. 1997b, Hamukuaya et al. 1998). Low oxygen levels near the seabed have also affected the distribution of hake over the Namibian shelf (Mas-Riera et al. 1990, Woodhead et al. 1998).

The Namibian Ministry of Fisheries and Marine Resources (MFMR) has the task of providing relevant oceanographic information to fisheries management, as input towards improving prediction of fish stock abundance and recruitment. However, such data are difficult to provide, because the underlying processes linking the environment to the resources are extremely complex and not well understood. The effects of dramatic environmental perturbations such as Benguela Niños (Stander and De Decker 1969, Shannon et al. 1986, Boyd et al. 1987, Gammelsrød et al. 1998) and widespread hypoxia (Hamukuaya et al. 1998, Woodhead et al. 1998) on the fish stock dynamics have been documented for the northern Benguela. Nevertheless, environmental information is available that can be used in a more general way to follow trends of important environmental processes. 
The aim of this paper is to illustrate how some environmental indicators were developed within the constraints and limitations of the available data. Interpretation of the developed indices is not the focus of this paper, although some important features are discussed. Useful indices would have to be maintainable for operational purposes, and be instructive to managers and scientists alike. Environmental indices serve as a measurement or proxy of the state or intensity of certain environmental processes or variables for comparison over time, which can be related to oceanographic processes affecting fish habitat conditions such as upwelling, frontal movements, anoxic bottom conditions, food availability, and water column stability. These environmental processes and conditions are particularly important during the early life stages of fish, when adverse environmental conditions can have a greater effect on fish stocks than during their adult phase (Bakun 1996).

\section{Material and Methods}

\section{Index identification and justification}

Seasonal and interannual variability

Wind-induced coastal upwelling is the most important oceanographic process along the Namibian coast (Shannon 1985, Boyd 1987, Boyd et al. 1987). Through this process, cool nutrient-rich water rises from depth to the surface where it stimulates primary production in the sunlit zone of the upper water column. Although increased upwelling increases the supply of nutrients to the surface and hence primary production, prolonged events can lead to the loss of production (phytoplankton, zooplankton, eggs and larvae) through mixing or turbulence and offshore advection (Bakun 1996). During periods of reduced upwelling (relaxed southerly winds), sea surface temperatures increase, leading to thermal stratification. The stratified surface layer benefits both primary and secondary production through enhanced vertical retention. The resultant thermoclines and fronts further serve as areas of high food concentrations which are especially beneficial to early life stages of fish.

\section{The Angola-Benguela Front}

The Angola-Benguela Front (ABF) is a sharp thermal front that separates the Angola and Benguela systems (Hart and Currie 1960, Shannon 1985). The Front refers to the convergence zone between the northward-flowing, cold and nutrient-rich Benguela Current and the southward-flowing,
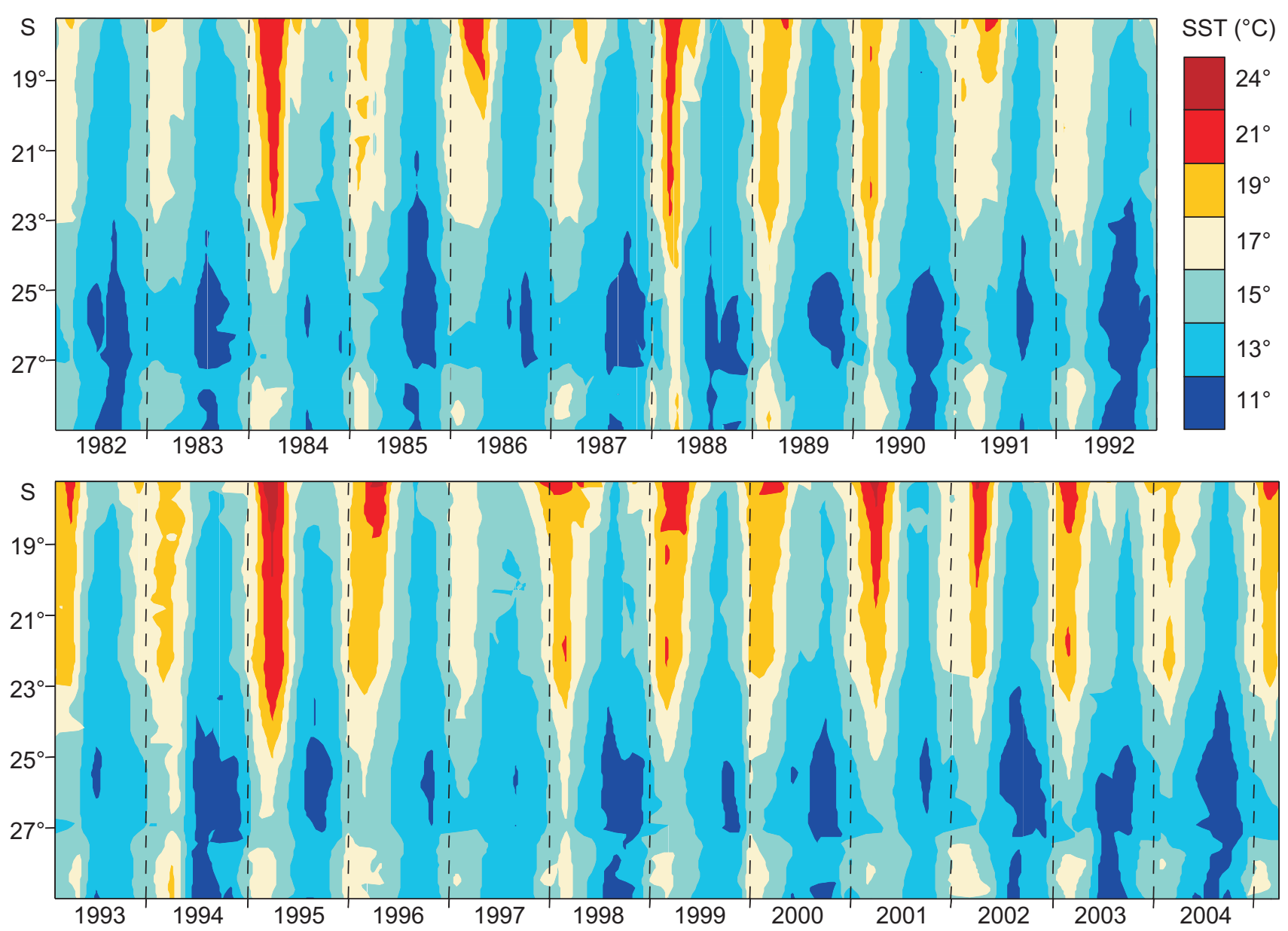

Figure 1: Monthly satellite-derived sea surface temperature (SST) averaged across a $60 \mathrm{~km}$-wide ocean strip along the Namibian coast 
warm, nutrient-poor Angola Current (Shannon 1985). It is a major feeding and spawning area for pelagic fish, as well as an ecological barrier that determines the northern distribution boundary for important Namibian fish stocks (Crawford et al. 1987, Beckley and van der Lingen 1999). The position of the ABF varies seasonally between approximately $14^{\circ} \mathrm{S}$ in winter and $17^{\circ} \mathrm{S}$ in summer/autumn (Shannon 1985, Meeuwis and Lutjeharms 1990).

\section{Temperature}

In summer, sea surface temperature (SST) can rise rapidly during extended quiescent periods. However, SST signals, especially from satellite imagery, can be very deceptive by falsely resembling Benguela Niño conditions. In situ measurements are necessary to confirm whether such surface signals extend deeper into the water column.

\section{Oxygen}

The central Benguela shelf region is characterised by perennially oxygen-depleted sub-thermocline waters, which in extreme cases can lead to hydrogen sulphide events (Bailey 1991). The low-oxygen conditions appear to result from a combination of local remineralisation of organic matter, as well as advection of remotely sourced oxygenpoor water (Chapman and Shannon 1985, Monteiro et al. 2004). The hypoxic conditions on the Benguela continental shelf can markedly impact on the local biota. Examples include commercially fished stocks, as evident from early nearshore mortalities of fish off Walvis Bay (Copenhagen 1953), hake Merluccius spp. recruitment failure off Walvis Bay in 1994 (Hamukuaya et al. 1998, Woodhead et al. 1997b) and hake recruit mortalities off Namibia in 1992/1993 (Woodhead et al. 1997a).

\section{Phytoplankton}

Phytoplankton forms the basis of the marine foodweb and chlorophyll $a$ is generally used as a proxy of phytoplankton biomass. Sedimenting phytoplankton production is the major contributor to unoxidised organic matter on the seabed, which results in oxygen-poor bottom conditions (Bailey 1991).

\section{Development of indices}

\section{Seasonal and interannual variability}

Satellite-derived SST has been applied to the Benguela region for more than two decades (Villacastin-Herrero et al. 1996, Cole 1997, Hardmann-Mountford et al. 2003, Roy et al. 2001). SST acts as a natural signature of many important oceanographic processes - such as upwelling, stratification, frontal development and movement (Meeuwis and Lutjeharms 1990). Therefore, a near real-time index derived from SST data, which is robust enough to identify major variations in upwelling, relaxation of upwelling, seasonal warming and the ABF movement, would be a useful tool for providing fisheries managers with information on the state of the marine environment. It could serve as a primary index from which more detailed information for process-specific or secondary indices could be extracted.
Four complete sets of all available weekly and monthly averaged SST images were compiled for both a highresolution $(1.1 \mathrm{~km}$; local area coverage [LAC]) and lowresolution $\left(4.4 \mathrm{~km}\right.$ and $1^{\circ}$; global areacoverage [GAC]) (source: http://iridl.Ideo.columbia.edu/SOURCES/.NOAA/. NCEP - IRI Data Library). The high-resolution data are restricted to the Namibian area $\left(8^{\circ}-17^{\circ} \mathrm{E}, 17^{\circ}-29^{\circ} \mathrm{S}\right)$, which limits their spatial application. The low-resolution data $\left(0.5^{\circ}-18.5^{\circ} \mathrm{E}\right.$ and $\left.0.5^{\circ}-30.5^{\circ} \mathrm{S}\right)$ are not area-restrictive, which is essential for detecting the ABF which straddles both the Angolan and Namibian regions. From these four datasets, the SST was extracted and averaged along a $60 \mathrm{~km}$-wide coastal band to produce two-dimensional datasets of averaged SST as a function of latitude and time (Figure 1). These serve as the primary indices. The band width represented on average the width of the Namibian shelf and its processes. For example, to show the southward intrusion of the Benguela Niño, which remains close to the coast, the band width should be narrow enough to detect the strong positive temperature anomalies that occur in that region.

\section{The Angola-Benguela Front}

The weekly and monthly latitudinal positions of various isotherms were extracted from the two-dimensional datasets, as indices of latitudinal migration of frontal structures (Figure 2). These indices can be interpreted in different ways. For example, Meeuwis and Lutjeharms (1990) identified the $20^{\circ} \mathrm{C}$ isotherm as an approximation of the southern boundary of the ABF. Anomalies of these isotherm positions were also calculated to quantify their interannual variations (Figure 3). It should be noted that a negative anomaly represents a negative SST anomaly, thus a more northerly position of the respective isotherm, and vice versa.

\section{In situ temperature}

In situ measurements are the only reliable data source to investigate the subsurface water column properties to verify the vertical extent of temperature in relation to anomalous events. Standard temperature measurements have been collected off central Namibia since 1950, and the station that has the most comprehensive temporal coverage is 10n.m. (nautical miles) off Walvis Bay. Data from that station were used to construct a temperature time-series index (Figure 4).

\section{Oxygen}

In situ dissolved oxygen measurements provided the best data source for the derivation of an oxygen-related index. The annual mean bottom oxygen distribution of the Namibian shelf shows that bottom oxygen levels are perennially below $2.0 \mathrm{ml} \mathrm{I}^{-1}$ over the shelf (Figure 5). In particular, the shelf area between $19^{\circ} \mathrm{S}$ and $24^{\circ} \mathrm{S}$ has bottom oxygen levels below $1.0-0.5 \mathrm{ml} \mathrm{I}^{-1}$ throughout the year, although there is some seasonal variation. The distribution of lowoxygen water $\left(<0.5 \mathrm{ml} \mathrm{I}^{-1}\right)$ mirrors the sediment distribution maps presented by Bremner (1983), where the highest percentage of organic matter was along the shelf $(0-200 \mathrm{~m})$ between $19^{\circ} \mathrm{S}$ and $26^{\circ} \mathrm{S}$. An oceanographic monitoring line 


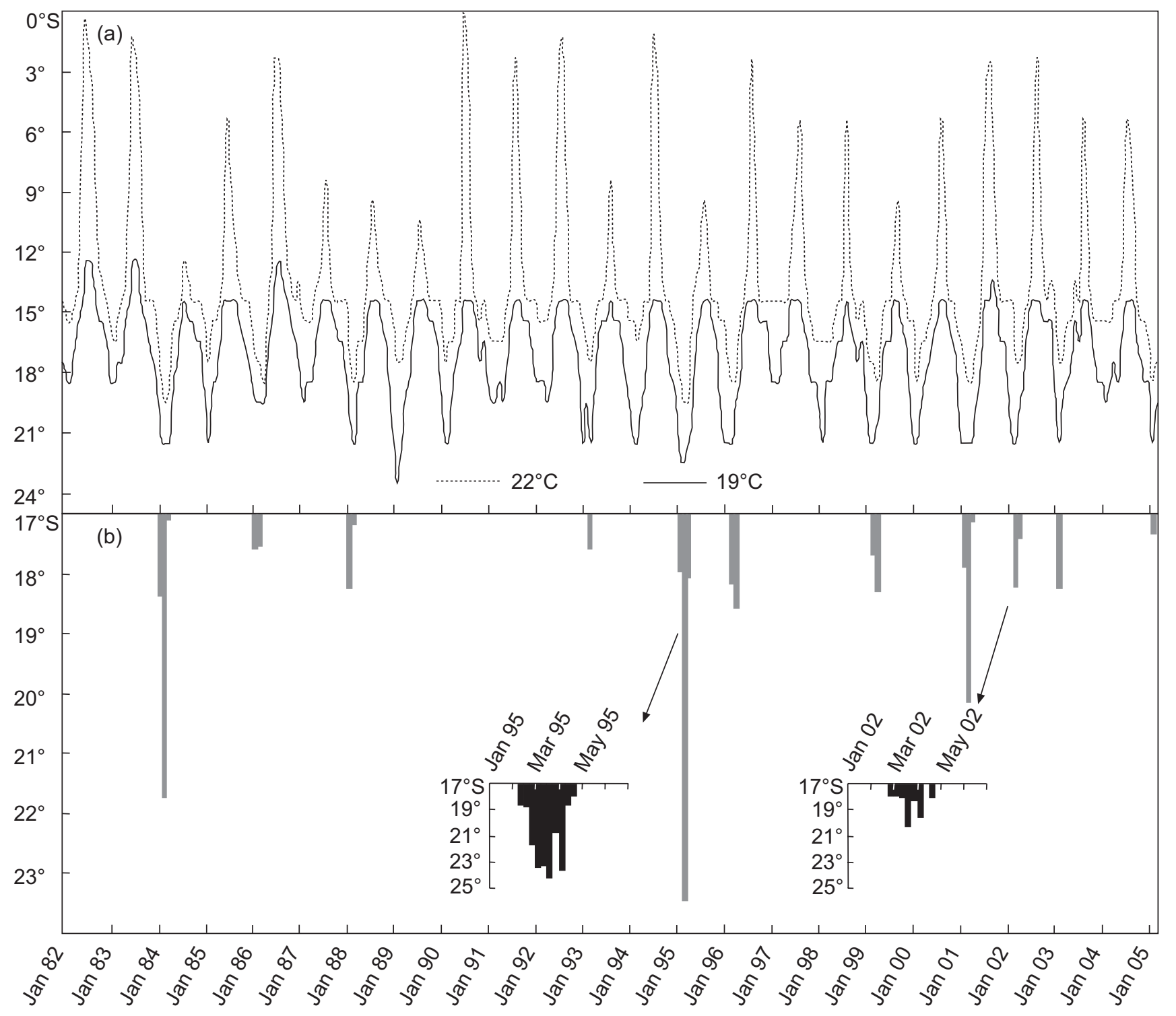

Figure 2: (a) Average monthly positions of the $20^{\circ} \mathrm{C}$ and $22^{\circ} \mathrm{C}$ isotherms within a $60 \mathrm{~km}$-wide coastal stretch along the Angolan and Namibian coastlines using GAC data; (b) latitudinal positions of the $22^{\circ} \mathrm{C}$ isotherm off Namibia using LAC data. The inserts show the weekly scale of warm-water intrusions during two selected periods, i.e. summer 1995 and 2002. All data are based on satellite-derived sea surface temperature

is sampled monthly by MFMR at $23^{\circ} \mathrm{S}$ (off Walvis Bay), at a position in the middle of this oxygen-poor region.

An areal computation was considered best to incorporate both the vertical and cross-shelf variation in low-oxygen water over the central Namibian shelf. However, the occasional midwater oxygen minimum found off the shelf could overshadow the actual oxygen status over the shelf where the main effects of low-oxygen waters are experienced. Therefore, the offshore area was excluded from the index calculation. Taking into consideration the perennially oxygen-poor nature of the bottom shelf waters off central Namibia, as well as the tolerance levels of important demersal species such as hake (Woodhead et al. 1998), a value of $0.5 \mathrm{ml} \mathrm{I}^{-1} \mathrm{O}_{2}$ was considered the critical level for the oxygen status over the shelf.

Data were extracted per survey for the entire water column along the monthly monitoring transect at $23^{\circ} \mathrm{S}$ from the coast to 50n.m. offshore (Figure 5) using a fixed depth grid. The volume/area calculation function of Surfer ${ }^{\circledR 8}$ (Golden Software Inc.) was used for calculating the percentage area of suboxic water $\left(<0.5 \mathrm{ml} \mathrm{l}^{-1}\right)$ over the transect (Figure 6).

\section{Phytoplankton}

In situ measurements are labour intensive and generally lack the temporal and spatial coverage to resolve phytoplankton dynamics. The advances in satellite sensor technology to measure chlorophyll a have partly solved this problem. Chlorophyll a concentration derived from highresolution SeaWiFS data was used as an indicator for phytoplankton biomass. A monthly dataset was processed to extract the average chlorophyll $a$ and anomalies along a $60 \mathrm{~km}$-wide coastal band as a function of time and latitude (Figure 7). 

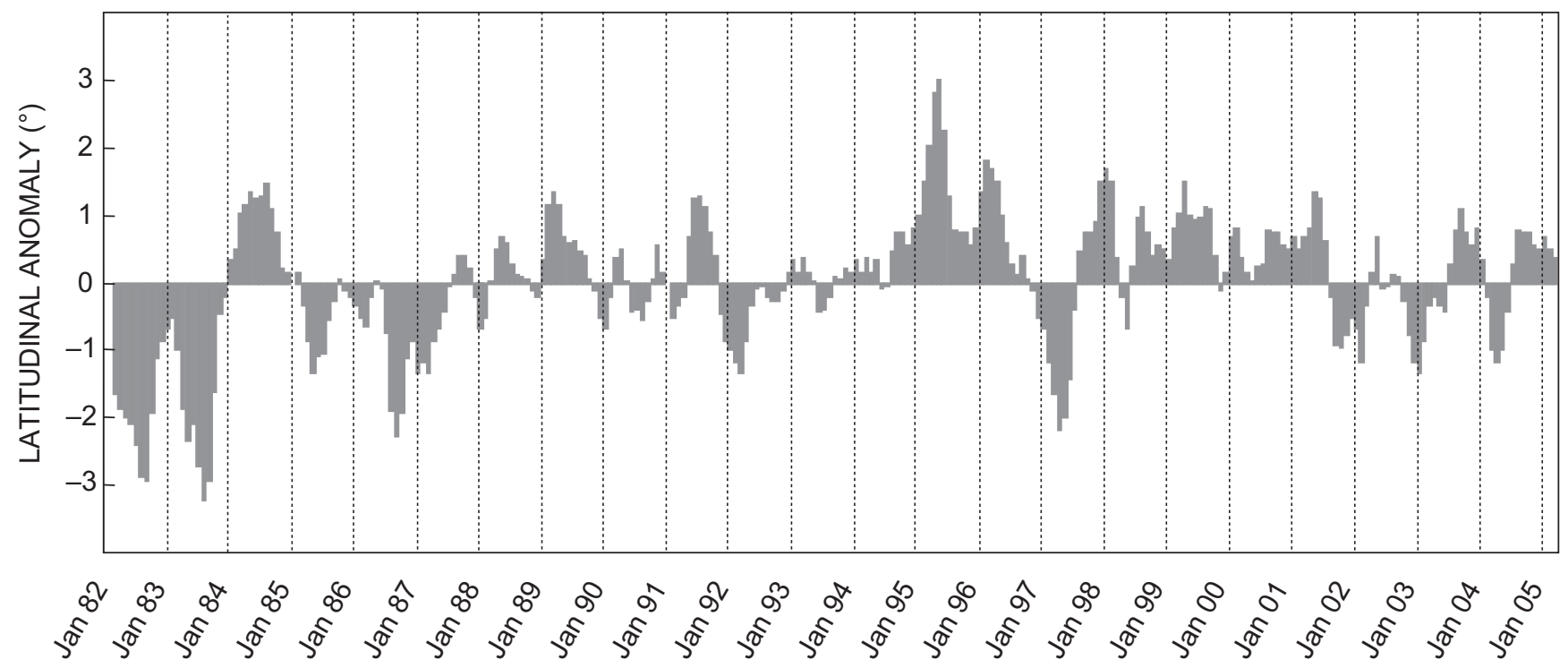

Figure 3: Latitudinal anomalies of the $20^{\circ} \mathrm{C}$ isotherm positions calculated for a $60 \mathrm{~km}$-wide band along the Angolan and Namibian coastline. Negative values indicate cool periods when the isotherm was farther north; positive anomalies indicate a more southerly position, i.e. during the 1995 Benguela Niño, the $20^{\circ} \mathrm{C}$ isotherm was around three degrees farther south than on average

\section{Results and Discussion}

\section{Seasonal and interannual variability}

The combination of solar insolation, seasonal relaxation of upwelling and the southward migration of the ABF during late summer and autumn results in the seasonal occurrence of warm SST off central and northern Namibia (Shannon 1985, Boyd 1987). The seasonal and interannual variability of this warming is clearly depicted in the primary index in Figure 1. Most of this interannual variability is related to fluctuations in upwelling intensity caused by local and/or remote wind-stress variability. In years when the upwelling relaxes for extended periods in summer (i.e. 1984, 1988, 1995, 1999, 2001, 2002 and 2003), warm-water events occur, and in years when upwelling is more active during the summer (i.e. 1982, 1983, 1987, 1992, 1997 and 2004), cooler conditions are experienced. The seasonal warming coincides with the latter half of the spawning season of most pelagic fish species (Le Clus 1985, 1990, Cole 1997). The optimum combinations of enrichment (upwelling), concentration and retention processes during that period are essential for larval survival and eventual recruitment (Cury and Roy 1989, Bakun 1996, Cole and McGlade 1998). Important components of these processes can be identified from this index; cool SST would represent upwelling or enrichment; stratification and frontal formations reminiscent of warmer SST would be representative of concentration and retention processes. Strong upwelling throughout the spawning period without any relaxations would be equally as detrimental to larval survival as would be extended periods of intense warming, such as the Benguela Niño periods in 1963 (Stander and De Decker 1969), 1984 (Shannon et al. 1986, Taunton-Clark and Shannon 1988) and in 1995 (Gammelsrød et al.1998). These events are clearly depicted in the index presented in Figure 4.

This index condenses large amounts of information into a single time-series, which shows such prominent features as the seasonality and interannual variability of upwelling, warmwater intrusions, and Benguela Niño events (Figure 4). The weekly version would be particularly useful to managers because it illustrates important short-term events. Specific thresholds or criteria for the identification of significant events, such as the Benguela Niño, could be inferred from these indices. For example, if the $20^{\circ} \mathrm{C}$ or $21^{\circ} \mathrm{C}$ isotherm extends southward of $23^{\circ} \mathrm{S}$ for at least two months, such as in 1984 and 1995 (Figure 1), managers could be alerted to the possibility of a Benguela Niño event. Additional in situ data should be incorporated at this stage to further verify the situation.

\section{Angola-Benguela Front}

The general south-north movement of the isotherms shown in Figure 2a represents the seasonal cycle, which is apparent for the $19^{\circ} \mathrm{C}$ and $22^{\circ} \mathrm{C}$ isotherms. During summer/ autumn, upwelling intensity off northern Namibia is low, which allows the Angola Current to penetrate farther south, and insolation is also at a maximum, resulting in high SST waters shifting southwards into Namibian waters. In winter/ spring, the converse is the case, with cooler SST retreating northwards of the Front. There is also a considerable amount of interannual variability in both the northern and southern positions of the isotherms. These variations characterise the differences in behaviour of the Front during various years. For example, during the Benguela Niño of 1984 and 1995, the southward extension of the isotherms during summer/autumn is much greater than during cooler years, i.e. 1987 and 1997 (Figure 2a, b).

There is also a marked difference between the weekly and monthly representation of the frontal movement, on 

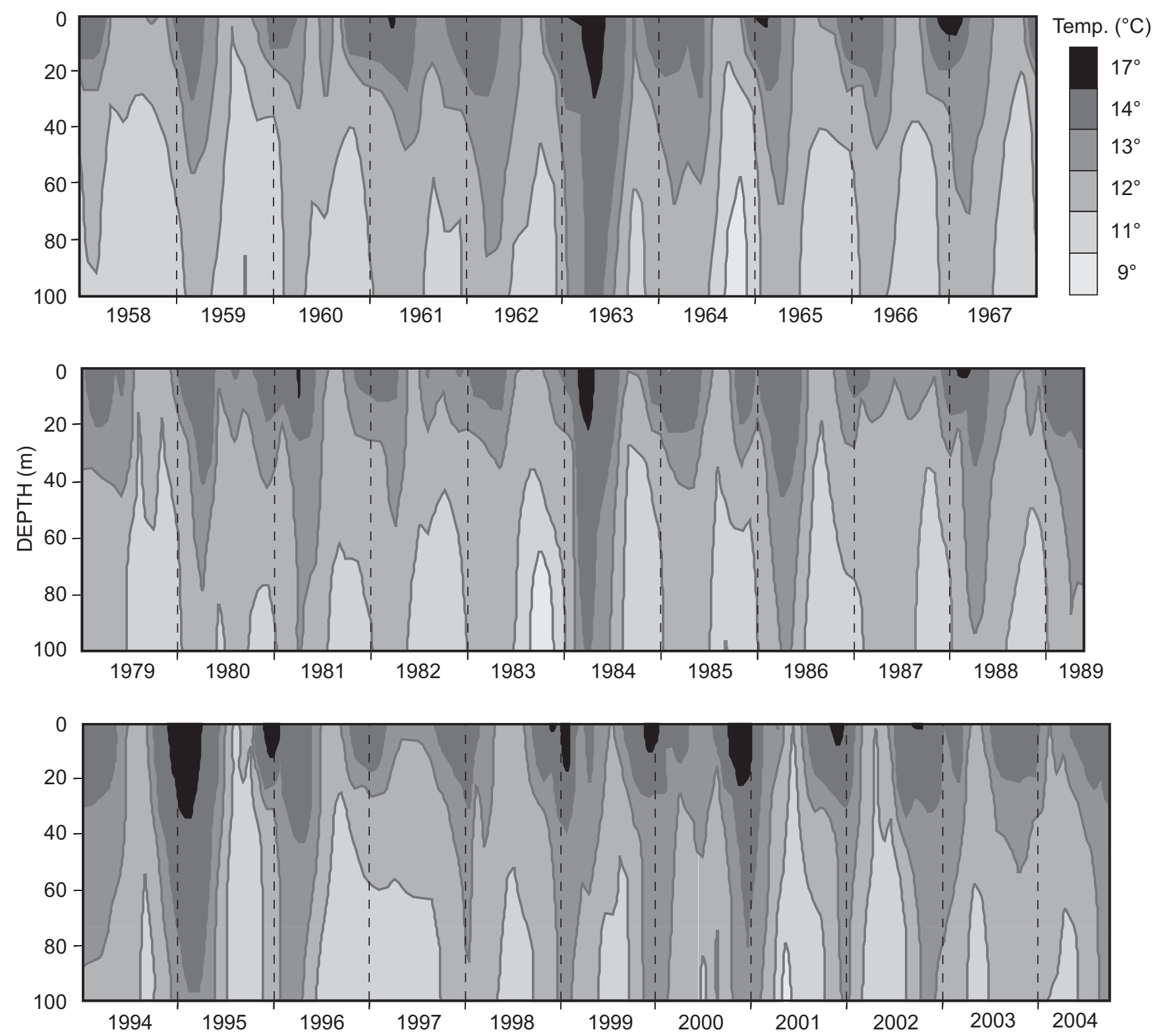

Figure 4: Time-series of water column temperature recorded at the Walvis Bay station during several research and monitoring programmes, 1958-2004. The in situ measurements indicate both surface and subsurface anomalies, i.e. cold-water and warm-water events

account of the different time scales involved. The 1995 warm-water occurrence is depicted as a single event extending from around January to March 1995, on the basis the $19^{\circ} \mathrm{C}$ isotherm and using the monthly scale (Figure 2a). However, on a weekly scale, the event consists of a series of warm events extended from January to March (Figure 2b). The timing of these intrusions also varies from year to year. Fish behaviour can be affected by such short bursts of warming or cooling, which could influence their migration spawning behaviour. Also, fish egg and larval survival can be affected if retention and/or food concentration is altered by such shortterm events (Cury and Roy 1989, Bakun 1996).

Anomalies of the isotherm positions shown in Figure 3 are useful to quantify the extent of warm- and cool-water events off Namibia and southern Angola - negative anomalies indicate cool years, i.e. isotherms being farther north than usual. Prior to 1988 , the system was dominated by an extended cool period, with three distinct cool years when the $20^{\circ} \mathrm{C}$ isotherm extended between one and three degrees farther north than on average (i.e. 1982, 1983 and 1987). In the past decade or so, there has been a higher frequency of warm-water events, including the 1995 Benguela Niño, and only one cool event in 1996-1997 (Figure 2). The monthly isotherm position of the $22^{\circ} \mathrm{C}$ isotherm is a good indicator of Benguela Niños and it clearly separates such major events from those less intense (Figures 1, 2a). The quasi realtime operational time frame makes it useful to management, more so than when used retrospectively only. It is interesting 


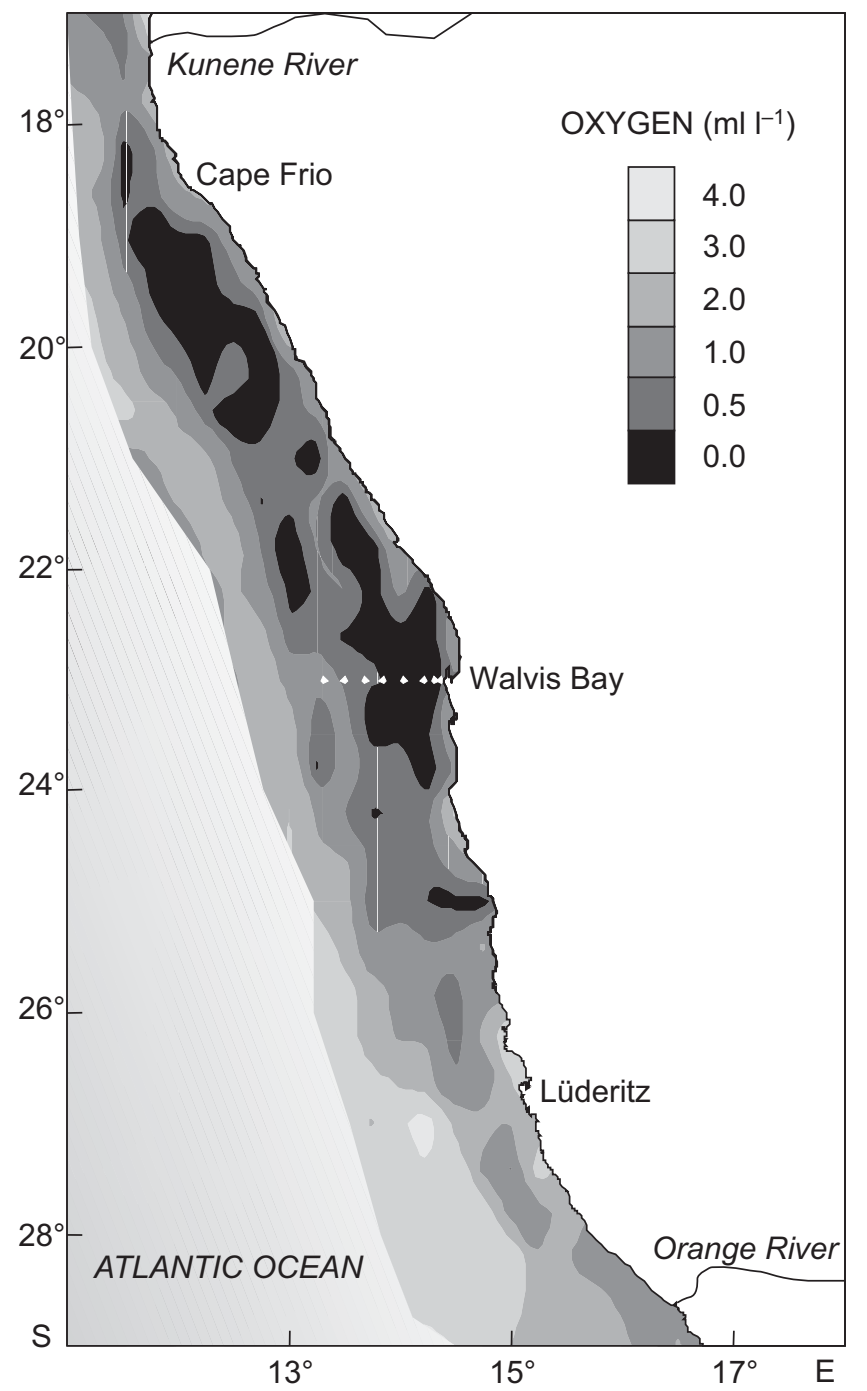

Figure 5: Average annual bottom oxygen concentration over the Namibian shelf. The Walvis Bay transect of stations is shown

to note, however, that, if the approximately 10-year interval between Benguela Niños held, then the next major event should have occurred in 2005; the index shows that this was not the case (Figures 1, 2a).

Although the GAC dataset has a coarse resolution and as such is unable to reflect subtle variations in latitudinal positions of the isotherm, major trends are reflected fairly clearly in the dataset (Figure 2a). Its advantages are the spatial coverage of the Angolan area, which is necessary for the tracking of the Front, and the quasi real-time nature of the data enables operational use of the index. The LAC dataset (Figure 2b) has a superior spatial resolution relative to the GAC dataset and is thus more accurate in determining isotherm movement; however, it does not cover the Angolan region.

\section{Temperature}

The station 10n.m. off Walvis Bay is positioned at the southern extremity of the area affected by the southward extension of the Angola-Benguela Front, which varies considerably during late summer and autumn. The $14^{\circ} \mathrm{C}$ isotherm usually extends to a depth of around $30-40 \mathrm{~m}$ during summer, but in cool years, such as 1983 and 1987, it is very shallow (Figure 4). In contrast, during the Benguela Niño years (1963, 1984 and 1995), the $14^{\circ} \mathrm{C}$ isotherm extends to depths close of the seabed at around $100 \mathrm{~m}$ (Figure 4). Many of the less intense warm-water events have similar surface signatures to those of Benguela Niño events and have often been identified as such anomalies from satellite imagery (Mohrholz et al. 2004). Therefore, care should be taken in interpreting such data.

\section{Oxygen}

Severely oxygen-depleted or anoxic bottom-water conditions are perennial over the central Namibian shelf region, specifically between $19^{\circ} \mathrm{S}$ and $24^{\circ} \mathrm{S}$ (Figure 5). Between summer and autumn (December-May), extremely low concentrations of dissolved oxygen occur over the shelf (Figure 6). This oxygen minimum is mainly a result of remineralisation of the sedimenting primary production (Bailey 1991), which peaks during spring and summer. Central Namibia is downstream of the main upwelling cell off Lüderitz, which is responsible for considerable organic input into the northern Benguela system. Somewhat higher dissolved oxygen levels occur during the spring upwelling period off central Namibia. Although the lower phytoplankton production during winter decreases the sedimentation rate of organic material during that period, the increased oxygen levels over the shelf are mainly on account of the re-oxygenation of the shelf water, as a result of oxygenated-water input from farther offshore during active upwelling. Monteiro et al. (2004) highlight the role of the non-linear interaction between the localscale and remote (basin)-scale forcing in determining the variability in low-oxygen water in the Benguela system. It appears that the variability in the advection of two different South Atlantic Central Water (SACW) masses, namely the hypoxic SACW of tropical origin (i.e. the Western South Atlantic Central Water [WSACW] ) and the more aerated Cape Basin SACW (i.e. the Eastern South Atlantic Central Water [ESACW]), onto the shelf contribute strongly to the interannual variability in the oxygen status of the Namibian shelf (Monteiro et al. 2006). This is depicted in the oxygen index shown in Figure 6. For example, the extensive lowoxygen bottom conditions that persisted from 2000-2001 could be ascribed to advection of more hypoxic WSACW onto the central Namibian shelf. However, in years when there was a stronger seasonal signal in low-oxygen variability (e.g. 1998, 1999, 2002 and 2003), it was likely on account of a strong influx of aerated ESACW onto the shelf (Figure 6).

Setting thresholds for bottom oxygen levels is necessary to identify major low-oxygen water events, and such thresholds should consider both the temporal and spatial scales of these events. For example, events that straddle two seasons, with no appreciable re-oxygenation of bottom waters during winter/spring (e.g. 2000-2001), should be classified differently than typical years in which there is a clear seasonal 


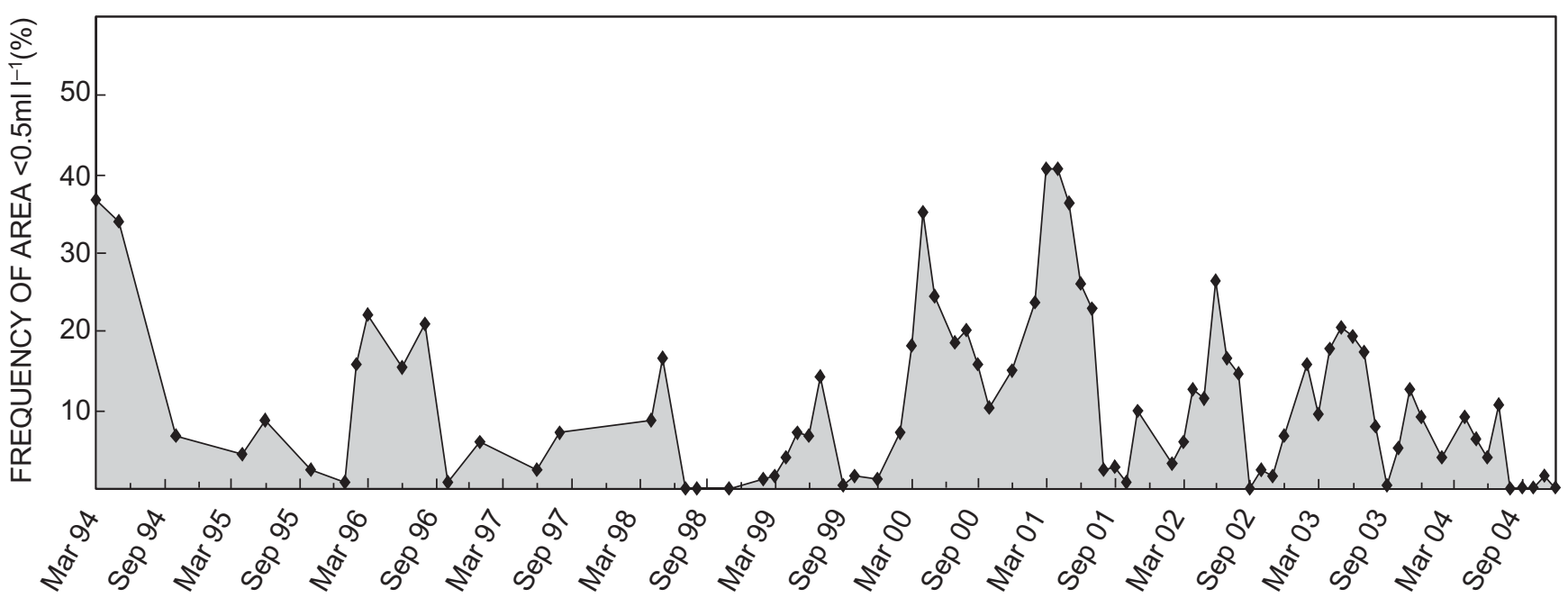

Figure 6: Monthly oxygen index of the percentage area of low-oxygen water $\left(<0.5 \mathrm{ml}^{-1}\right)$ present over the central Namibian shelf from samples taken from the Walvis Bay transect

trend and when oxygenation of bottom waters occurs. A major event could thus be described as one in which the presence of low-oxygen bottom water extends over one or more years without appreciable re-oxygenation during winter/spring, and where the event consistently occupies $>15 \%$ of the water column above the shelf. This may be tested by applying a seasonal (3-monthly) moving average to the oxygen index values and ascertaining that the average area of low-oxygen water remains above $15 \%$.

A Kreiner (MFMR, unpublished data) investigated the effect of low-oxygen water on pelagic fish eggs and larvae and proposed a threshold of $>2.5 \mathrm{ml} \mathrm{I}^{-1}$ as significant for the survival of these larvae. Such indices could be easily derived if sufficient data are available. The oxygen index could also be created for other regularly monitored regions, such as the monitoring line over the lobster reefs off Lüderitz.

A more complete assessment of the oxygen status along the Namibian coast could be obtained by sampling transects to the south and north of the Walvis Bay monitoring line. However, in situ dissolved oxygen measurements are both costly (ship's time) and labour intensive (requiring extensive calibration for each survey) constraints that limit oxygen indices as effective inputs to operational models.

\section{Phytoplankton}

Satellite-derived chlorophyll a represents the surface phytoplankton distribution and abundance. High abundances occur mainly off central Namibia - which correlates well spatially with the high bottom organic carbon distribution found in that region (Bremner 1983, Monteiro et al. 2004) - but lack the strong seasonal signal exhibited by SST (Figure 7a). Strong turbulence and vigorous mixing in the upper ocean layer inhibits phytoplankton growth in upwelling centres such as the Lüderitz cell, as shown by the low chlorophyll a concentrations in that area (Agenbag and Shannon 1988). The low phytoplankton biomass off northern Namibia and southern Angola exhibits a clearer seasonal signal and is linked to the southward advection of nutrient-poor Angolan surface water in summer/autumn. During a warm event in 2001, the index depicts the pronounced southward extension of the nutrient-poor Angolan water (Figure 7a). It is also possible to extract chlorophyll a or anomalies thereof for larger areas, i.e. the central shelf, in order to present more general summaries of phytoplankton abundance.

\section{Conclusion}

The examples of indices developed and discussed here clearly illustrate the usefulness of such tools for identifying and tracking anomalous environmental perturbations and for displaying general long-term trends in the northern Benguela system. Although wind-derived indices are generally used as indicators in upwelling systems, it is illustrated here that symptoms thereof, such as temperature and chlorophyll a variability, or thermal frontal movements such as the Angola-Benguela Front, can be used with some confidence to illustrate environmental variability.

By setting thresholds to quantify the intensity of anomalous events such as warm-water intrusions, Benguela Niños or low-oxygen water, the value of information supplied can be upgraded to a level that managers can (re)act according to defined mitigation procedures. However, the indices presented here only reflect environmental conditions and do not integrate the effect of environmental variability on biological processes such as fish spawning and recruitment. Environmental variability plays an important role in fish dynamics in the northern Benguela, especially during their early life history stages Voges et al. (2002). Future research effort should focus on improving understanding of the role that environmental variability plays in recruitment success and catchability of the commercial fish resources by identifying and developing resource-applied environmental indices. 

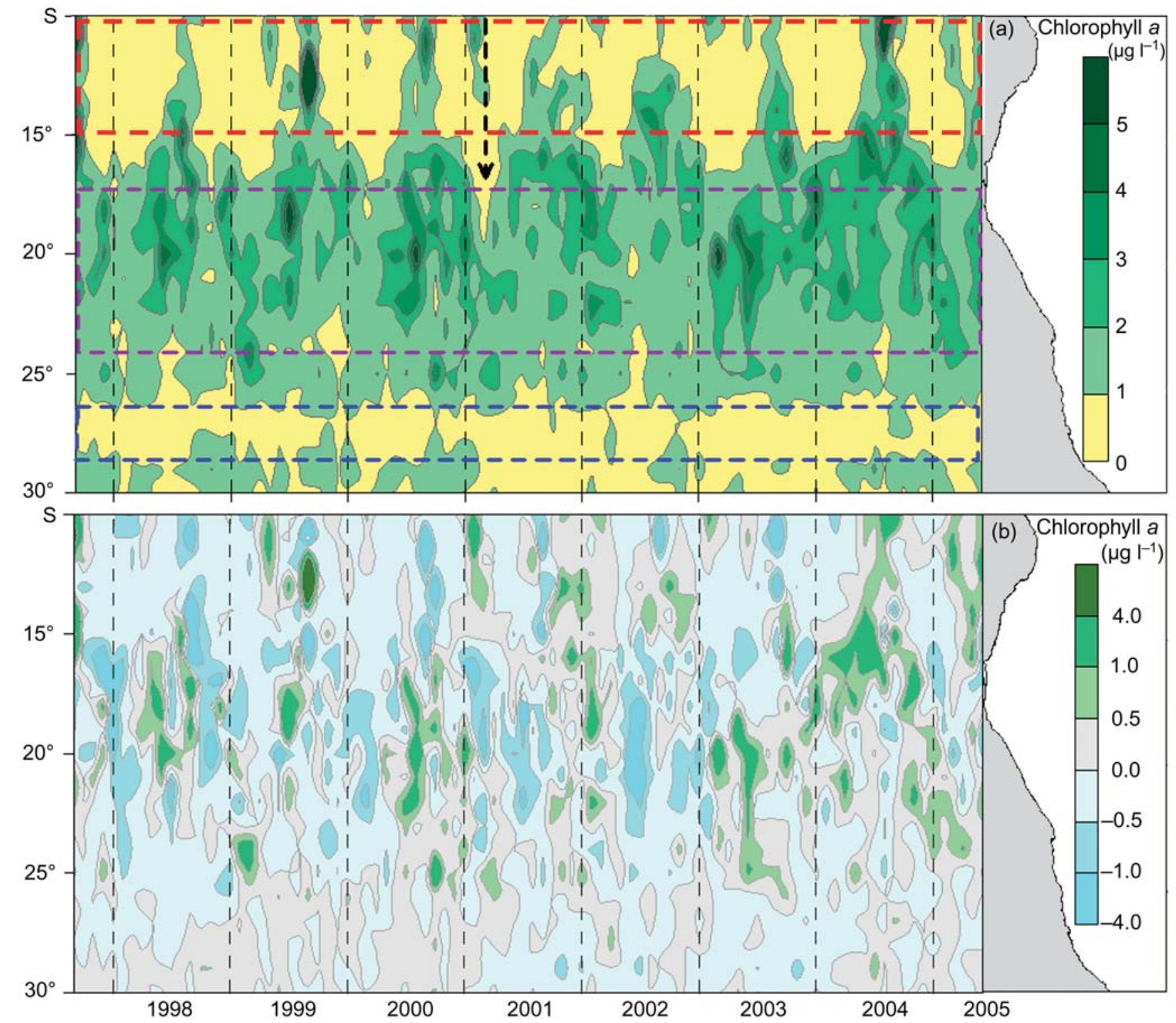

Figure 7: (a) Hovmöller plot of the average monthly chlorophyll a over a 60km-wide ocean strip along the southern Angolan and Namibian coastlines from September 1997 to June 2005. The blue box indicates the low-production area off Lüderitz, the purple box indicates the area of higher chlorophyll a off central to northern Namibia and the red box indicates the area off northern Namibia and southern Angola where there is a strong seasonal signal of chlorophyll a. The black arrow indicates the 2001 summer/autumn season when the southward advection of low-nutrient Angolan water was particularly intense, i.e. low chlorophyll a; (b) a representation of the monthly chlorophyll a anomaly over a 60km-wide ocean strip along the southern Angolan and Namibian coastlines

Acknowledgements - We thank the Namibian Ministry of Fisheries and Marine Resources for its support, as well as all our colleagues that were involved in the data collection - particularly the staff of the Environmental Subdivision. We are grateful to the German GTZ and the BENEFIT programme for financial support and to the SeaWiFS Science Project for access to SeaWiFS data.

\section{References}

Agenbag JJ, Shannon LV (1988) A suggested physical explanation for the existence of a biological boundary at $24^{\circ} 30^{\prime} S$ in the Benguela System. South African Journal of Marine Science 6 : 119-132
Bailey GW (1991) Organic carbon flux and development of oxygen deficiency on the modern Benguela continental shelf south of $22^{\circ} \mathrm{S}$ : spatial and temporal variability. In: Tyson RV, Pearson TH (eds) Modern and Ancient Continental Shelf Anoxia. Geological Society Special Publication 58: 171-183

Bakun A (1996) Patterns in the Ocean: Ocean Processes and Marine Population Dynamics. Centro de investigaciones Biologicas del Noroeste, La Paz, Mexico, and University of California Sea Grant, San Diego

Baumgartner T, Struck U, Alheit J (2004) GLOBEC investigation of interdecadal to multi-centennial variability in marine fish populations. PAGES News 12: 19-21

Beckley LE, van der Lingen CD (1999) Biology, fishery and 
management of sardines (Sardinops sagax) in southern African waters. Marine and Freshwater Research 50: 955-978

Boyd, AJ (1987) The oceanography of the Namibian region. PhD thesis, University of Cape Town, South Africa

Boyd AJ, Salat J, Maso M (1987) The seasonal intrusion of relatively saline water on the shelf off northern and central Namibia. South African Journal of Marine Science 5: 107-120

Boyer DC, Hampton I (2001) An overview of the living marine resources of Namibia. In: Payne AIL, Pillar SC, Crawford RJM (eds) A Decade of Namibian Fisheries Science. South African Journal of Marine Science 23: 5-35

Bremner JM (1983) Biogenic sediments on the South West African (Namibian) continental margin. In: Thiede J, Suess E (eds) Coastal Upwelling: its Sedimentary Record, Part B: Sedimentary Records of Ancient Coastal Upwelling. Plenum Press, New York, pp 73-104

Chapman P, Shannon LV (1985) The Benguela Ecosystem Part II. chemistry and related processes. In: Barnes M (ed) Oceanography and Marine Biology: An Annual Review 23: 183-251

Cole JFT (1997) The surface dynamics of the northern Benguela upwelling system and its relationship to patterns of clupeoid production. PhD thesis, University of Warwick, UK

Cole JFT, McGlade J (1998) Temporal and spatial patterning of sea surface temperature in the northern Benguela upwelling system: possible environmental indicators of clupeoid production. In: Pillar SC, Moloney CL, Payne AIL, Shillington FA (eds) Benguela Dynamics: Impacts of Variability on Shelf-Sea Environments and their Living Resources. South African Journal of Marine Science 19: 143-157

Copenhagen WJ (1953) The periodic mortality of fish in the Walvis region; a phenomenon within the Benguela Current. Investigational Report Division of Sea Fisheries, South Africa 14: $35 \mathrm{pp}$

Crawford RJM, Shannon LV, Pollock DE (1987) The Benguela ecosystem. Part IV. The major fish and invertebrate resources. Oceanography and Marine Biology: An Annual Review 25: 353-505

Cury P, Roy C (1989) Optimal environmental window and pelagic fish recruitment success in upwelling areas. Canadian Journal of Fisheries and Aquatic Sciences 46: 670-680

Gammelsrød T, Bartholomae CH, Boyer DC, Filipe VLL, O'Toole MJ (1998) Intrusion of warm surface water along the AngolanNamibian coast in February-March 1995: the 1995 Benguela Niño. In: Pillar SC, Moloney CL, Payne AIL, Shillington FA (eds) Benguela Dynamics: Impacts of Variability on Shelf-Sea Environments and their Living Resources. South African Journal of Marine Science 19: 41-56

Hamukuaya H, O'Toole MJ, Woodhead PMJ (1998) Observations of severe hypoxia and offshore displacement of Cape hake over the Namibian shelf in 1994. In: Pillar SC, Moloney CL, Payne AIL, Shillington FA (eds) Benguela Dynamics: Impacts of Variability on Shelf-Sea Environments and their Living Resources. South African Journal of Marine Science 19: 57-61

Hardmann-Mountford NJ, Richardson AJ, Boyer DC, Kreiner A, Boyer H (2003) Relating sardine recruitment success in the northern Benguela to environmental conditions during spawning estimated from satellite-derived sea surface temperature and height. Progress in Oceanography 59: 241-255

Hart TJ, Currie RI (1960) The Benguela Current. Discovery Reports 31: 123-297

Le Clus F (1985) Effect of a warm water intrusion on the anchovy stock off South West Africa to pre-1983 levels. Collection of Scientific Papers. International Commission for the Southeast Atlantic Fisheries 11: 99-106

Le Clus F (1990) Impact and implications of large scale environmental anomalies on the spatial distribution of spawning of the Namibian pilchard and anchovy populations. South African Journal of Marine Science 9: 141-159
Mas-Riera J, Lombarte A, Gordoa A, Macpherson E (1990) Influence of Benguela upwelling on the structure of demersal fish populations off Namibia. Marine Biology 104: 175-182

Meeuwis JM, Lutjeharms JRE (1990) Surface thermal characteristics of the Angola-Benguela Front. South African Journal of Marine Science 9: 261-279

Mohrholz V, Schmidt M, Lutjeharms JRE, John H-C (2004) Spacetime behaviour of the Angola-Benguela Frontal Zone during the Benguela Niño of April 1999. International Journal of Remote Sensing 25: 1337-1340

Monteiro PMS, van der Plas AK, Bailey GW, Fidel Q (2004) Low oxygen variability in the Benguela ecosystem: a review and new understanding. CSIR Report ENV-S-C 2004-075. Centre for Marine Studies, University of Cape Town, and CSIR, Stellenbosch

Monteiro PMS, van der Plas AK, Mohrholz V, Mabille E, Pascall A, Joubert W (2006) The variability of natural hypoxia and methane in a coastal upwelling system: oceanic physics or shelf biology? Geophysical Research Letters 33: L16614. doi: 10.1029/2006 GL026234

Parrish RH, Bakun A, Husby D, Nelson DS (1983) Comparative climatology of selected environmental processes in relation to eastern boundary current pelagic fish reproduction. In: Sharp GD, Csirke J (eds) Proceedings of the Expert Consultations to Examine Changes in Abundance and Species Composition of Neritic Fish Resources, San Jose, Costa Rica. FAO Fishery Report 291(2): 731-777

Payne AlL (1989) Cape hakes. In Payne AIL, Crawford RJM (eds) Oceans of Life off Southern Africa. Vlaeberg, Cape Town, pp 136-147

Roy C, Weeks S, Rouault M, Nelson G, Barlow R, van der Lingen CD (2001) Extreme oceanographic events recorded in the southern Benguela during the 1999-2000 summer season. South African Journal of Science 97: 465-471

Shannon LV (1985) The Benguela Ecosystem Part I. Evolution of the Benguela, physical features and processes. Oceanography and Marine Biology: An Annual Review 23: 105-182

Shannon LV, Boyd AJ, Brundrit GB, Taunton-Clark J (1986) On the existence of an El Niño-type phenomenon in the Benguela system. Journal of Marine Research 44: 495-520

Shannon LV, Nelson G (1996) The Benguela: large scale features and processes and system variability. In: Wefer G, Berger WH, Siedler G, Webb DJ (eds) The South Atlantic: Present and Past Circulation. Springer-Verlag, Berlin, pp 163-210

Stander GH, De Decker AHB (1969) Some physical and biological aspects of an oceanographic anomaly off South West Africa in 1963. Investigational Report Division of Sea Fisheries, South Africa 81: 46pp

Taunton-Clark J, Shannon LV (1988) Annual and interannual variability in the South-East Atlantic during the 20th century. South African Journal of Marine Science 6: 97-106

van der Westhuizen, A (2001) A decade of exploitation and management of the Namibian hake stocks. In: Payne AIL, Pillar SC, Crawford, RJM (eds) A Decade of Namibian Fisheries Science. South African Journal of Marine Science 23: 307-315

Villacastin-Herrero CA, Underhill LG, Crawford RJM, Shannon LV (1996) Sea surface temperature of oceans surrounding subequatorial Africa: seasonal patterns, spatial coherence and longterm trends. South African Journal of Science 92: 189-197

Voges E, Gordoa A, Field JG, Batholomae C (2002) Estimating the probability of different levels of recruitment for Cape hakes Merluccius capensis off Namibia, using environmental indices. Fisheries Research 58: 333-340

Woodhead PM, Hamukuaya H, O'Toole MJ, McEnroe M (1998) Effects of oxygen depletion in shelf waters on hake populations off central and northern Namibia. In: Shannon V, O'Toole MJ (eds) International Symposium, Environmental Variability in the 
South East Atlantic. National Marine Information and Research Centre, Namibia

Woodhead PM, Hamukuaya H, O'Toole MJ, Strømme T, Kristmannsson S (1997a) Recruit mortalities in Cape hake, following exclusion from shelf habitat by persistent hypoxia in the Benguela Current, Namibia. In: ICES International Symposium, Recruitment Dynamics of Exploited Marine Populations: Physical-Biological Interactions, September 22-24 1997, Baltimore, Maryland, pp 26-27
Woodhead PM, Hamukuaya H, O'Toole MJ, Strømme T, Saetersdal G, Reiss M (1997b) Catastrophic loss of two billion Cape hake recruits during widespread anoxia in the Benguela Current off Namibia. In: ICES International Symposium, Recruitment Dynamics of Exploited Marine Populations: Physical-Biological Interactions, September 22-24 1997, Baltimore, Maryland, pp 105-106 